\title{
THE CULT OF ST BRUNO IN LITHUANIA: LITURGICAL AND HAGIOGRAPHICAL ASPECTS
}

\author{
Liudas Jovaiša
}

ABSTRACT The veneration of St Bruno of Querfurt has never been particularly prominent in Lithuania. Until the very beginning of the twenty-first century Lithuania had no church, chapel or altar dedicated to the saint. Neither were the images of this martyr saint known except those in the seventeenth-century cycle of fresco scenes in the Camaldolese monastery in Pažaislis. Nevertheless, St Bruno, generally known as St Boniface, the apostle of Rus', has been mentioned in the liturgical calendars of Lithuanian dioceses and religious orders and also in various Polish and Lithuanian lives of saints since the late seventeenth century. The present paper deals with the liturgical and hagiographical aspects of the saint's veneration.

In Lithuania the cult of St Bruno of Querfurt has never been particularly distinct. His following in the footsteps of St Adalbert was fateful in that there simply remained no place for St Bruno in the memory of the loca ${ }^{1}$ Catholic Church. His predecessor, the apostle of Prussia, St Adalbert became the first patron saint of Poland and Gniezno, the place of his relics, turned into the ecclesiastical capital of the state. Since St Bruno's relics did not survive, a centre for his cult did not emerge, and the place of the patron saint of Poland had already been 'occupied'. Rus' found itself within the sphere of influence of the Orthodox Church, meanwhile Prussia, Lithuania, and Yotva, the lands visited by the sainted missionary, were still heathen. Until the early twenty-first century there was no church, chapel or altar bearing the name of St Bruno of Querfurt. No other images of the saint martyr were known except those in the fresco cycle of the Camaldolese monastery in Pažaislis. ${ }^{1}$ Nevertheless, it must be acknowledged that St Bruno's name has appeared in the liturgical calendars of Lithuanian dioceses and religious orders and in various publications of the lives of saints since the end of the seventeenth century.

${ }^{1}$ This fresco cycle is described in detail in Mindaugas Paknys' article in the present issue. 
Before going into any more detail in this research, it is necessary to indicate that the sources dealing with St Bruno's life give two names to the saint - Bruno and Boniface. Some of the accounts, for instance that of the Camaldolese St Peter Damian, refers to the saint martyr only as Boniface, while others, only as Bruno. Other accounts, giving both names of the saint, were unknown for a long time; consequently, Cardinal Cesare Baronio, writing a history of the Church and preparing Roman martyrology in the sixteenth century, distinguished two saints - the apostle of Rus' St Boniface (his feast day 19 June) and St Bruno, a Prussian missionary (feast day 15 October). This inadequate treatment of the personality of St Bruno of Querfurt was noticed first only in the early eighteenth century, ${ }^{2}$ but the old tradition died hard and in the liturgical calendar (including that of Lithuanian dioceses and religious orders) the separate appearances of St Boniface and St Bruno continued until the very twentieth century.

\section{Patronus Regni Poloniae et Magni Ducatus Lithuaniae On} 21 January 1673 at the request of the king of Poland and the Monte Corona Congregation of the Camaldolese Order, the Sacred Congregation of Rites allowed the celebration of the feast day of St Boniface (i.e. St Bruno of Querfurt ${ }^{3}$ ) as a semiduplex feast throughout the Kingdom of Poland. The same decree held good for the Grand Duchy of Lithuania - that was attested by Officium $S$. Bonifacii Martyris Ordinis Eremitarum Camaldulensium S. Romualdi, semiduplex (...) die 19 Iunii recitandum, published by the press of the Academy of Vilnius in the same year. ${ }^{4}$ This modest four-page publication contained the decree of the Sacred Congregation of Rites and the readings (IV-VI) of the breviary for that day about St Boniface's life.

2 On the history of the discovery and interpretation of the sources about St Bruno's mission in greater detail, see Inga Leonavičiūte, ‘Šv. Brunono Kverfurtiečio ciklo šaltiniai’, 1009 metai: Šv. Brunono Kverfurtiečio misija / A.D. 1009: missio S. Brunonis Querfordensis (= Fontes ecclesiastici historiae Lithuaniae, 5), ed. Inga Leonavičiūtè (Vilnius, 2006), pp. 217-219.

${ }^{3}$ Since the sixteenth century liturgical and hagiographical literature erroneously presented the saint as two persons: St Boniface, the bishop and martyr of Rus' (feast day 19 June) and St Bruno of Querfurt, the apostle and martyr of Prussia (feast day 15 October).

${ }^{4}$ Two copies of this publication are kept in the of Rare Books Room of the Vilnius University Library. 
By this decree St Boniface became one of the patron saints of Poland-Lithuania. ${ }^{5}$ The 1725 liturgical calendar of the Diocese of Vilnius marked 19 June as festum semiduplex ad libitum of $\mathrm{St}$ Boniface, patron saint of the kingdom of Poland. ${ }^{6}$ This feast was held in some other dioceses, e.g. in Žemaitija ${ }^{7}$ and Lutsk $^{8}$ and in the dioceses of Minsk $^{9}$ and of Augustów-Sejny ${ }^{10}$, established in the early nineteenth century already after the annexation of the GDL. It is noteworthy that in cases when feasts of a higher rank (e.g. the Feast of Corpus Christi and its octave) fell on 19 June, the liturgical celebration of St Boniface's feast day was often moved to some later date.

The observance of St Boniface's feast day occupied a special place in the liturgical calendar of the Mogilev archdiocese, which was established by Catherine II after the first partition of the Commonwealth. Here St Bruno was venerated on 18 June by a feast of a higher rank - sub ritu duplici - as the patron saint of Russia. The special status of the Mogilev feast was expressly indicated in the 1805 calendar of the archdiocese: S. Bonifacii E. M. Patr. Ross. dx (hac die colitur in Nostra Dioecesi, extra hanc semiduplex, atque diem aliam sibi assignatam habet, inter Patronos Poloniae 19 hujus ponitur). ${ }^{11}$ As a patron saint of Russia St Boniface was mentioned later as well, e.g. in the 1829 liturgical calendar. ${ }^{12}$ In 1863 he was titled only as a patron saint of the diocese; but nevertheless he was

${ }^{5}$ Cf. Missae propriae patronorum et festorum Regni Poloniae et Sueciae ad normam Missalis Romani accommodatae (Vratislaviae MDCCLXXVI). The cited festum semiduplex is 19 June.

${ }^{6}$ A copy without the title page: LMAB RS, L-20/930/1725.

${ }^{7}$ See Directorium horarum canonicarum et missarum (...) pro dioecesi Samogitiensi in annum Domini MDCCCXX, Vilnae [s.a.]; Ordo divini officii et missarum ad usum dioecesis Samogitiensis seu Telsensis, pro anno Domini MCMXII (Vilnius, 1911), p. 38.

${ }^{8}$ See Directorium horarum canonicarum et missarum ss. pro dioecesi Luceoriensi in annum Domini MDCCCLXII (Vilnius, 1861), pp. 27-28.

${ }^{9}$ See Directorium divini officii ac missarum SS. pro dioecesi Minscensi in annum Domini MDCCCLX (Vilnius, 1859), pp. 26-27.

${ }^{10}$ See Directorium divini officii ad usum (...) dioecesis Sejnensis seu Augustoviensis (...) pro anno Domini MCMI, Varsaviae, s.a., p. 47.

${ }^{11}$ Directorium officii divini et missarum generale pro utroque clero archidioecesis Mohileviensis in anno Domini MDCCCV (...), Mohileviae, s.a.

${ }^{12}$ Directorium officii divini ac missarum ad usum archidioecesis Mohileviensis pro Anno Domini MDCCCXXIX, Mohileviae, s.a. 
venerated by a feast of a still higher rank - duplex maius. ${ }^{13}$ The 1898 liturgical calendar showed that the feast of the patron saint of the Kingdom of Poland and of the Mogilev archdiocese was already moved to its usual date -19 June. ${ }^{14}$

The heritage of the Commonwealth of the Two Nations in the form of the cult of St Boniface ${ }^{15}$ survived throughout the entire nineteenth century until the political reforms which resulted in the rise of modern republics of Poland and of Lithuania. In the aftermath of the establishment of the Lithuanian ecclesiastical province with the capital in Kaunas the remnants of the heritage of the Commonwealth of the Two Nations were finally removed from the liturgical calendar in 1926. ${ }^{16}$

St Bruno's feast day on 15 October has never featured in the liturgical calendars of the Lithuanian dioceses. First, St Bruno has never been among the patron saints of Poland and Lithuania and his feast was celebrated only in the dioceses of Warmia and Sambia. Second, in the diocese of Vilnius 15 October was a double (duplex) feast day of its patron saint Teresa, consequently there was no place for one more saint - even the feast day of St Jadwiga was moved to 17 October. ${ }^{17}$

\section{St Boniface in the Calendar of Vilnius Diocese in the Early} Twentieth Century Strange and puzzling changes were taking place in the liturgical calendar in Vilnius at that time. The 1911 calendar still indicated 19 June as the usual semiduplex feast, but in the 1917 calendar 5 June (sic) was marked as the duplex maius feast day of the bishop and martyr St Boniface, the second patron

${ }^{13}$ Directorium horarum canonicarm et missarum pro archidioecesi Mohyloviensi in annum Domini MDCCCLXIII (...), Vilnae, 1862, p. 22.

${ }^{14}$ Directorium divini officii et missarum pro archidioecesi Mohiloviensi in annum Domini 1898, Wilno, 1898, p. 75.

${ }^{15}$ Sometimes, in particular in the latter half of the nineteenth century, the abbreviation P. R. P. (Patronus Regni Poloniae) disappeared from the pages of the calendar (e.g. in the 1870 calendar of Vilnius diocese), but was soon re-introduced again.

16 St Boniface's feast day was already not found in the 1915 calendar of the diocese of Žemaitija, cf. Ordo divini officii et missarum ad usum Samogitiensis seu Telsensis dioecesis pro anno Domini MCMXV. St Boniface was not mentioned in the 1916 calendars of the Mogilev archdiocese and the Minsk diocese, see Directorium Divini officii et missarum pro archidioecesi Mohiloviensi necnon pro dioecesi Minscensi in annum Domini bissextilem 1916, s.1.e.a.

${ }^{17} \mathrm{Cf}$. Missae propriae patronorum et festorum. 
saint (minus principalis). ${ }^{18}$ The officia propria, published by the diocese of Vilnius and approved by Blessed Jurgis Matulaitis ${ }^{19}$ showed that on the feast days of the same rank - duplex maius - the following saints were venerated in the diocese: St Vincent Kadłubek (8 March), St Adalbert (24 April), Blessed Andrew Bobola (16 May), Blessed Kunigunda (24 July), the transfer of St Casimir's relics (26 August), the Holy Name of Mary (12 September), Blessed Ladislaus of Gielniow (25 September), the transfer of St Stanislaus' relics (27 September), Blessed John of Dukla (1 October), thanksgiving for the victory at Chocim (10 October), and St Nicholas (6 December). The feasts of a higher rank - duplex II classis - were dedicated to St Stanislaus Kostka (13 November) and the Blessed Virgin Mary, Mother of Mercy of the Gates of Dawn (16 November). The highest liturgical feasts - duplex I classis with the octave - were celebrated to honour Ss Casimir, George, and Stanislaus.

In the above-mentioned 1919 publication St Boniface was mentioned only as a bishop and martyr and not patron saint of the country, diocese or cathedral. It also reprinted breviary readings (matutinum IV-VI) from the 1673 publication about the life and martyrdom of St Boniface based on St Peter Damian's accounts, and a short prayer ${ }^{20}$ and references to other breviary texts ${ }^{21}$ of that day.

It is unknown by whom and why the rank of St Boniface's feast day was changed in the diocese of Vilnius. It is noteworthy that the feast day was moved to 5 June on which St Boniface, apostle of Germany, was venerated by the Universal Church. Could not there be a mistake due to confusing the two Bonifaces? The 1939 calendar of the archdiocese of Vilnius marked 5 June as the duplex feast of the saint bishop and martyr Boniface. Was in this case 'our' St Bruno Boniface meant, or maybe, after the correction

18 Ordo divini officii recitandi missaeque celebrandae ad usum insignis eccl. cathedralis et dioecesis Vilnensis (...) pro anno Domini MCMXVII compositus, Vilnae, s.a., p. 99.

${ }^{19}$ Officia propria dioecesis Vilnensis iuxta calendarium a S. Sede adprobatum, s.a. [1919]. Its copy is kept in LMAB.

${ }^{20}$ Oratio. Deus, qui nos beati Bonifacii Martyris tui atque Pontificis annua solemnitate laetificas, concede propitius, ut cuius natalitia colimus, de eiusdem etiam protectione gaudeamus. Per Dominum, Officia propria dioecesis Vilnensis, p. 63.

${ }^{21}$ Ibid. Ant. et Pss. ad oo. Horas et vv. Nocturnorum de currenti hebd. die, ut in Psalt.; rel. de Comm. Martyr., praeter ea, quae sequuntur [i. e. Oratio et Lectiones]. 
of the mistake, the apostle of Germany? The liturgical calendar of the newly-established Lithuanian dioceses (of Kaunas, Panevezzys, Kaišiadorys and Telšiai) and of the entire ecclesiastical province of Lithuania has also designated 5 June as the duplex feast day of St Boniface, most probably the eighth-century bishop and martyr. ${ }^{22}$

Traces of St Bruno Boniface's Cult in the Calendars of Religious Orders In the majority of the liturgical calendars of the religious orders in Lithuania - unlike those of the dioceses - St Bruno was not highly venerated until the early twentieth century. June 19 was celebrated on the same diocesan semiduplex level only by the Trinitarians, ${ }^{23}$ the Discalced Carmelites, ${ }^{24}$ and the Canons Regular of the Lateran. ${ }^{25}$ St Boniface seems to have been honoured in some way by the Dominicans ${ }^{26}$ and the Carmelites of the Mitigated Rule ${ }^{27}$ as well, but there was not any allusion to this saint in the calendars of the Augustinians, Bernardines, Conventual Franciscans and Jesuits. However, the feast day of St Boniface occupied a special place in the Lithuanian monasteries of the Benedictine Rule - the Benedictine orders of monks and nuns and the Camaldolese hermits.

${ }^{22}$ Cf. Ordo divini officii recitandi missaeque celebrandae pro anno Domini 1939 ad usum dioecesis Kaišedorensis, s.l.e.a., p. 78; Ordo divini officii recitandi missaeque celebrandae ad usum dioecesis Panèvežensis (Naples, 1939), p. 62; Ordo divini officii recitandi missaeque celebrandae pro anno Domini 1938 ad usum Archidioecesis Kaunensis (Naples, 1937) (an inscription sub 4 June: De S. Bonifacio nihil hoc anno); Ordo divini officii recitandi missaeque celebrandae pro anno Domini 1944 ad usum dioecesis Telšensis, s.l.e.a., p. 48; Ordo divini officii recitandi missaeque celebrandae pro anno Domini 1946 ad usum provinciae ecclesiasticae in Lituania (Kaunas, 1946), p. 63.

${ }^{23}$ See Directorium horarum canonicarum et missarum (...) ad usum FF. Ord. SSS. Trinitatis provinciae S. Joachim (...) pro anno Domini MDCCCLX (Vilnius, 1859), p. 16 (here St Boniface is referred to as a patron of Poland).

${ }^{24}$ See Directorium divini officii recitandi missarumque celebrandarum ad usum fratrum ac monialium ordinis carmelitarum discalceatorum in Rossia (...) pro anno Domini MDCCCLIX (Vilnius, 1858), p. 23.

${ }^{25}$ See Directorium divini officii et missarum pro Congregatione Canonicorum Regularium Lateranensium in annum MDCCCLXI conscriptum (Vilnius, 1860), p. 15 .

${ }^{26}$ See Directorium divini officii recitandi (...) Sacri Ordinis Praedicatorum in Provincia Lituaniae pro Anno Domini MDCCCXLVI, Vilnae, s.a.; Directorium divini officii recitandi missaeque celebrandae (...) Sacri Ordinis Praedicatorum (...) pro provincia Lithuaniae et Russiae in annum MDCCCLXIII (Vilnius, 1862), p. 23.

${ }^{27}$ Directorium divini officii recitandi missarumque celebrandarum (...) ordinis fratrum B. V. D. Genitricis Mariae de Monte Carmelo (...) in annum Domini 1861 (...) (Vilnius, 1860), p. 19. 
In Officia propria Patronorum Ordinis S. Benedicti ad usum sanctimonialium ordinis eiusdem (Vilnius, 1648) there was not a single hint of St Boniface or St Bruno. Meanwhile Officia propria SS. Patronorum Sacri Ordinis Divi Benedicti, compiled by the confessor of Vilnius Benedictine nuns, Chryzostom Zygmunt Zdrowski, and published possibly by the abbess of the same house, Marcybella Joanna Grużewska, in 1684, indicated that the feast day of the bishop and martyr Boniface was usually celebrated on 19 June, and its rank was higher - it was duplex. ${ }^{28}$ This publication again reprinted the 1673 breviary readings about St Boniface's life and martyrdom and the text of a prayer ${ }^{29}$ Interestingly, an undated manuscript, produced by Benedictine nuns in approximately the same period ${ }^{30}$ (the attribution to Bogumiła Bykowska OSB is much later), did not mention St Boniface at all. Meanwhile here the commemoration (commemoratio) of the bishop and martyr St Bruno was indicated sub 15 October. He was presented as a Ruthenian bishop (episcopus Ruthenorum) and a monk of the order of St Benedict; in 1008 he was martyred for preaching the gospel, first by cutting off his hands and legs and finally his head. ${ }^{31}$

Thus at the turn of the seventeenth century the liturgical calendar of the Benedictine order presented two alternative forms of the veneration of St Bruno of Querfurt: 19 June as the duplex feast day of St Boniface and 15 October as the feast day of St Bruno. In the eighteenth century one more local variant appeared in the Benedictine communities: the feast day or commemoration (not quite clear) of St Boniface on 20 June. That was attested by a Benedictine calendar issued by Karol Andrzejowski, ${ }^{32}$ a professed monk of

28 Officia propria SS. Patronorum Sacri Ordinis Divi Benedicti ex recenti breviario benedictino desumpta (...) in gratiam sanctimonialium ejusdem Ordinis (...) (Vilnius, 1681), pp. 101-103.

29 Oratio. Infirmitatem nostram respice, omnipotens Deus: et quia pondus propriae actionis gravat, Beati Bonifacij, Martyris tui atque Pontificis, intercessio gloriosa nos protegat. Per Dominum etc., ibid., p. 101.

${ }^{30}$ The manuscript could be of some later provenance, possibly of the nineteenth century. That would explain why St Bruno but not St Boniface is mentioned in it (more on that see later) and why its provenance note is so 'belated'.

${ }^{31}$ Eodem die natalis est etiam sancti Brunonis Episcopi Ruthenorum et martyris, ex monacho nostri ordinis, qui Evangelium in ea regione praedicans, ab impiis tentus, manibus pedibusque praecisis, capite truncatus est anno Domini millesimo octavo, indictione sexta, [Officium Sanctorum], LMAB, L-17/176/1, unnumbered pages.

${ }^{32}$ Kalendarz benedyktyński na każdy dzień catego roku życiem świętych Pańskich Zakonu S. Oyca y Patryarchy (...) Benedykta (...) przez X. Karola Andrzejowskiego (...) do druku podany, d. 1 (Vilnius, 1768), p. 611. 
the Lubin monastery and a confessor of Vilnius Benedictine nuns, and by the calendar of the Holy Cross Congregation of the Polish Benedictines (to which Lithuanian monasteries belonged, too). ${ }^{33}$ The tradition to honour St Boniface on 20 June could have been taken by the Benedictines from the Camaldolese calendar, according to which St Romuald's disciple as a saint of this order was venerated by the duplex II classis feast on 20 June, and 19 June was the feast day of St Romuald. ${ }^{34}$

In the nineteenth century the organizational structure of the monasteries underwent many changes. After the Final Partition of the Commonwealth the traditional ties among the monasteries belonging to the same province or congregation were severed. Several monasteries following the Rule of St Benedict - the Benedictines, Cistercians, Camaldolese, and Carthusians - on the territory of Russia were united into one common congregation. The calendars issued by this congregation did not feature St Boniface's name, ${ }^{35}$ instead 15 October was indicated as St Bruno's feast day. ${ }^{36}$ Why the Benedictine calendar replaced St Boniface's feast day on 19/20 June by St Bruno's commemoratio on 15 October is unknown. Maybe some learned monk discovered in a certain source, e.g. in Acta Sanctorum, that these two persons should be identified as one?

St Bruno's Liturgical Veneration in Lithuania at the Turn of the Twentieth Century At the beginning of the twentieth century the veneration of St Bruno Boniface was waning rapidly. The majority

33 Directorium divini officii (...) pro Commoditate monachorum sub Regula S. P. Benedicti Congregationis Polonae Sanctae Crucis (...) in Annum Domini $M D C C L X X X V I$ ordinatum, Lublin, s.a. This publication comprises an indefinite allusion about the liturgical veneration of St Boniface at the monasteries of Lubin, Warsaw, Sieciechow and Senieji Trakai on 20 June.

${ }^{34}$ Cf. Directorium divini officii (...) ad usum eremitarum Camaldulensium Congregationis Montis Coronae degentium in Regnis et Provinciis S. C. R. A. Majestati nec non Ser. Reg. Polon. et Magn. Duc. Lithuaniae subjectis pro anno Domini M.DCC.LXIX, Viennae, s.a.

${ }^{35}$ In the margins of a copy of the 1797 calendar of the Minsk diocese a certain Benedictine monk mentioned the feast day of S. Bonifacij Ep. M. O. N. d. a. ex 19 hujus (shifted to 20 June), cf. Directorium horarum canonicarum et missarum (...) pro Anno Domini MDCCXCVII (...) ecclesiarum in praefecturis Minscensi et Volhinensi sitarum, Berdiczoviae, s.a., VUB, Rubr. 38 / 1797.

${ }^{36}$ Directorium divini officii juxta ritum monasticum persolvendi (...) in commodum monachorum sub Regula S. P. N. Benedicti in Imperio Rossiae degentium (...) in Annum Domini MDCCCXXX ordinatum, Vilnae, s.a.; mention is made about Com. S. Brunonis E. M. in L. et Mis. 
of the monasteries of the Rule of St Benedict were closed, and after the First World War in the aftermath of the establishment of independent Lithuania the patron saint of the old Republic lost his former relevance. The revival of the cult of St Bruno of Querfurt was promoted by the example of neighbouring Polish dioceses. In 1963 the saint was named the first patron of the diocese of Lomża and the second patron of the diocese of Warmia. Since in the calendar of the Universal Church the feast day of St Bruno was celebrated during the Lent (9 March), in Poland this festival was shifted first to 15 July and later to 13 July. After the Second Vatican Ecumenical Council the Liturgical Commission was established at the Lithuanian Episcopal Conference, and work on the preparation of the Lithuanian missal began. According to the secretary of this Commission Vaclovas Aliulis, MIC, in the course of this work some corrections were made in the liturgical calendar of the Lithuanian dioceses as well. At the suggestion of a member of the Commission St Bruno of Querfurt, as St Boniface (Bruno), was introduced as the second patron saint of the diocese of Vilnius. ${ }^{37}$ His feast day (12 July) was taken from an updated liturgical calendar of the Polish dioceses. ${ }^{38}$ Following the endorsement and publication of the new missal the veneration of St Boniface Bruno began in the archdiocese of Vilnius with obligatory memoria on 12 July. ${ }^{39}$ When, following Jurgis Matulaitis' beatification, 12 July became his feast day, St Boniface Bruno's veneration was shifted to 13 July in the archdiocese of Vilnius. ${ }^{40}$ This practice continued until 2009 when 9 March was instituted by the calendar of the Universal Church for the memoria obligatoria of St Bruno in Lithuania, too. ${ }^{41}$

\section{St Boniface's 'Lives' in the Period of the Grand Duchy of} Lithuania Piotr Skarga was the first to present a biography of the saint in his famous Lives of the Saints, first published in Vilnius in $1579 .{ }^{42}$ The missionary's life was not issued separately - it was

37 Edvardas Gudavičius observed the connection between Lithuania and St Bruno's mission in his article published in 1983. The same idea had been expressed by the Liturgical Commission in the context of the reform of the calendar and effectively implemented several years earlier!

${ }^{38}$ The author of this article is grateful to Aliulis for this information.

${ }^{39}$ Kataliku kalendorius-žinynas 1982 (Kaunas-Vilnius, 1982), p. 36.

${ }^{40}$ Kataliku kalendorius-žinynas 1988 (Vilnius, 1988), p. 35.

${ }^{41}$ Liturginis kalendorius 2008-2009 (Vilnius, 2008), pp. 47-48.

42 Żywoty Świętych Starego i Nowego Zakonu na każdy dzień przez caly rok przez Ks. Piotra Skarge (Vilnius, 1579), pp. 575-576. 
added to St Romuald's life sub 21 June (although the running title on page 576 said that it was the 'Life of St Boniface, a Russian Apostle'). The basis of St Boniface's life presented by Skarga was St Peter Damian's account. At the end of the biography the renowned preacher and polemist of Vilnius accentuated the significance of the mission of St Boniface as the apostle of Rus'. ${ }^{43}$ The biographer was not surprised at the significance of the missionary's activity as he was deeply concerned about the issue of the union between the Churches: in 1577 his famous book on Church unity ( $O$ jedności Kościoła Bożego pod jednym pasterzem i o greckim od tej jedności odstepieniu) had appeared in Vilnius.

Afterwards the breviary readings about St Boniface's life and martyrdom were also edited taking into account Damian's texts, and they were read without any changes for over two centuries between 1673 and the early twentieth century. ${ }^{44}$ Interestingly, the readings contained a phrase, missing in Damian's account, that St Boniface arrived at the coast of the Baltic Sea (sic) and preached a sermon to a Russian king. ${ }^{45}$ Damian's evidence was also very valuable to Karol Andrzejowski who left the most comprehensive account of St Boniface's life in the times of the GDL. ${ }^{46}$ Besides, this author indicated some other sources: Florentin. Historye Kameldulenskie. Petrus de Natalibus. Buzelin y inni. ${ }^{47}$

In his account Andrzejowski closely followed Damian, but rather freely presented details. Thus, Damian wrote that Boniface saw the church of the holy martyr and German apostle Boniface (videns ecclesiam antiqui martiris Bonifatii), ${ }^{48}$ while according to Andrzejowski he saw St Boniface's image (ile razy przechodzit

${ }^{43}$ Obacz czytelniku: 1. Isz Ruskie krainy nie tylko do Greków, ale y od Rzymskiego Kościoła nawrócone sq do wiary (...). Znać pewnie, isz na poczatku u Rusi Rzymskie y Łacińskie koscioły byty (...) 2. Badź tesz tego pewien, isz Ruś na poczqtku prawowierna y Katholickq wiare, gdy ieszcze na on czas y Grekowie w postuszeństwie koscioła Rzymskiego żyli, przyięli (...), ibid., p. 576.

44 Officium s. Bonifacii martyris (1673) and Officia propria dioecesis Vilnensis (1919).

${ }^{45}$ Denique ubi ad littora Baltici maris pervenit, coram Rege Ruthenorum Christum praedicans, cf. Officia propria SS. Patronorum Sacri Ordinis Divi Benedicti (...) (Vilnius, 1681), p. 102.

${ }^{46}$ Kalendarz benedyktyński (...), pp. 611-614.

${ }^{47}$ Ibid., p. 614, Petrus de Natalibus, Catalogus Sanctorum et gestarum eorum, Venetiis 1493 (first edition); Historiarum Camaldulensium libri iii. auth. Aug. Florentino, Florentiae, 1575.

48 Cited after 1009 metai: Šv. Brunono Kverfurtiečio misija, p. 194. 
koło Obrazu Bonifacego Świętego...). ${ }^{49}$ A typical peculiarity of Andrzejowski's style was a genuine 'Sarmatian' narrative: very vivid and detailed but wholly fictional descriptions of the scenes of Boniface's mission. ${ }^{50}$ The author was not aware of the exact date of the martyr's death - he indicated approximately the year 1000; according to him St Boniface immediately after his consecration went to Rus', certainly through Poland, since Rus' definitely was a part of Poland... ${ }^{51}$ St Boniface's life by Andrzejowski was the last known hagiographical account of the saint written in Polish in the GDL. Bishop Motiejus Valančius' particular attention to Lithuanian literature and the formation of the modern (Catholic) Lithuanian nation in the nineteenth century opened the way for Lithuanian hagiographical writings.

\section{St Bruno Boniface's 'Lives' in the Lithuanian Hagiographical} Literature of the Twentieth Century The first lives of the saints in the Lithuanian language were prepared and issued by Bishop Motiejus Valančius of Žemaitija in $1858 .{ }^{52}$ This little book comprised only the lives of the saints whose names were most popular in Žemaitija at that time. Naturally, St Boniface was not presented in it. Neither was the name of this saint listed in other more extensive publications: Visu metu gyvenimai šventuju by Serafinas Laurynas Kušeliauskas (1889) and Šventuju mūsu globèju gyvenimai by J. Baltrušaitis issued in Seinai (1908); the latter comprised only some 'national' saints (Ss Casimir, Adalbert and Stanislaus) associated with the old Commonwealth).

${ }^{49}$ Kalendarz benedyktyński, p. 611.

${ }^{50}$ Cf. the missionary's dialogue with the king: Przyiat Król Bonifacego, lubo odartego, w prostym Zakonnym Habicie, y bosego, y rzecze do niego: Po coś tu przyszedt $w$ postaci żebraka do mnie? izali potrzebujesz złota albo sukień? wraz tobie dać każę, tylko tym czasem niechciey prawić baiek babskich, bo styszałem, że jakiegoś Boga Zawieszonego na Krzyżu opowiadasz, ale jak ciebie obdarować jałmużnq każe, wraz mi się wynoś z Państwa moiego. Odpowiada Bonifacy: Miałem dosyć bogactwa y wszelkich dostatkow na swiecie, alem temi dla milosci Chrystusowej statecznie wzgardzil; pochodzę z zacney Krwi y pokolenia, alem się stal policzony między ubogie, bo ktorzykolwiek dobrowolnie dla milosci Boga staiq się ubogiemi, ci osiagaia Niebo; a zas bogaczom ciasna droga iest do Nieba, przeto częstokroc nie trafiaia do niego, ibid., p. 612.

${ }^{51}$ Skoro wkroczyt $w$ granice Polskie (bowiem Ruś jest część Polski), wraz zaczynat Apostolstwo swoje (...), ibid.

52 Ziwataj szwętuju, tu kuriu wardajs żemajczej uż wis gieb wadinties (...) (Vilnius, 1858). 
St Boniface's life was first printed in Lithuanian most probably in 1927 in a three-volume publication containing short accounts of the lives of saints assigned for every day of the year (re-issued in the USA in 1945). ${ }^{53}$ The life of St Boniface, 'the Russian apostle and martyr', was presented sub 15 March, possibly because in the opinion of the compiler 'the feast day of St Boniface has not yet been definitely established to date'. ${ }^{54}$ In the book the date of the martyrdom, as usually based on Damian's account, was indicated 'about 1008 '. At the end a short exhortation was added: 'Wherever necessary, God confirms the holy truth of faith with a miracle. He performed such a miracle in order to facilitate the conversion of the Russian people. However, we should not require from God new signs to confirm those truths which have been confirmed incalculably (sic) through the ages. ${ }^{55}$

The lives of the saints issued by Fr Kazimieras A. Matulaitis, MIC, occupy a special place in twentieth-century Lithuanian hagiography. ${ }^{56}$ St Bruno's biography sub 2 December, presented on five pages, is the most extensive in the book. St Bruno's life, featured in this book, marks a new tradition in local hagiography. First, the story goes about St Bruno of Querfurt rather than about St Boniface ('Brunonas or Bruno is known to Lithuanians as Šv. Bonifacas' ${ }^{57}$ ). Second, the author cites not only St Peter Damian but also, and not to a lesser extent, Wipert, an author of a concise account of St Bruno's martyrdom, written in the Tegernsee monastery, Bavaria, in the eleventh century. Third, Bruno's mission takes place no more in Rus' but in Prussia; the names of these two regions are accounted for by introducing the personality of the Prussian king of Rusne (Prūsu Rusnès karalius). ${ }^{58}$ Finally, this biography witnesses the significance of St Bruno's martyrdom for Lithuania: it is associated with the first mention of the name of Lithuania in the Magdeburg Annals. 'St Bruno's death was not in vain since it brought the Faith to the land of Prussia. ... Thanks to St Boniface the Prussians and

${ }^{53}$ Ištisu metu šventuju gyvenimai, t. 1-3 (Kaunas, 1927-1928). Šv. Bonifaco gyvenimas, t. 1, pp. 188-191.

${ }^{54}$ Ibid., p. 191.

55 Ibid.

56 Šventuju gyvenimai kiekvienai metu dienai (Chicago, 1949). Šv. Brunono gyvenimas, pp. 637-642.

${ }^{57}$ Ibid., p. 637.

58 Ibid. p. 640. 
their neighbours the Lithuanians became acquainted with Christ's teaching at the beginning of the eleventh century'. ${ }^{59}$ The story of St Bruno's life ends with a reminder about his feast day on 19 June and a concise exhortation: 'Great deeds require great sacrifice, even life, in order to make God's name familiar, honoured, and loved'. ${ }^{60}$

Conclusion The Lithuanian history of the veneration of St Bruno of Querfurt is intricate and complex. Therefore, a meticulous absorption in its various meanders could create an erroneous impression that the missionary was better known and more fully appreciated than he actually was. A universally known historical personality, associated with the first mention of Lithuania's name, St Bruno has not yet become a truly honoured saint, a benefactor and an example of Christian life in Lithuania.

As Lithuania celebrates the millennium of the mention of her name, St Bruno is receiving special attention in the Lithuanian Catholic Church as well. The first Lithuanian parish of St Bruno of Querfurt was founded in Klaipeda on 7 January 2007, and the year 2009 was declared by the Lithuanian bishops a special anniversary year of 'the Gospel for the Millennial Lithuania'. ${ }^{61}$ It is to be hoped that the anniversary would stimulate the recovery and knowledge of the missionary St Bruno whose martyr death became the birthday of Lithuania.

Translated by Alfoncas Laučka

Author Details

Dr Liudas Jovaiša is a lecturer of the Faculty of History of the University of Vilnius and a member of the Lithuanian Institute of Cultural Research. His scholarly interests are the history of the Roman Catholic Church in the Grand Duchy of Lithuania; he is a compiler, editor or co-author of the publications Žemaičiu vyskupijos vizitacija (1579) (1998), Benediktiniškoji tradicija Lietuvoje (2008), Lietuvos Didžiosios Kunigaikštijos kultūra: Tyrinejjimai ir vaizdai (2001), Krikščionybès Lietuvoje istorija (2006), and Lietuvos kataliku dvasininkai XIV-XVI a. (2009).

Address: Faculty of History, University of Vilnius, Universiteto g. 7, Vilnius, LT-01131

Email: liudas.jovaisa@gmail.com

${ }^{59}$ Ibid., pp. 637-638, 642.

${ }^{60}$ Ibid., p. 642.

${ }^{61}$ The anniversary year was declared by Lithuanian bishops on 30 November 2008, the first Sunday of Advent, in the pastoral letter, see Artuma, no. 12, 2008. 


\title{
ŠV. BRUNONO KULTAS LIETUVOJE: LITURGINIS IR HAGIOGRAFINIS ASPEKTAS
}

\author{
Santrauka
}

\section{LIUDAS JOVAIŠA}

Šv. Brunono Kverfurtiečio kultas Lietuvoje niekada nebuvo itin ryškus, ir nors iki pat XXI a. pradžios šv. Brunonui Lietuvoje nebuvo dedikuota jokia bažnyčia, koplyčia ar altorius, šis šventasis buvo minimas liturginiame kalendoriuje ir įvairiuose Šventujų gyvenimu leidimuose.

Liturginiame kalendoriuje iki pat XX a. vyravo XVI a. atsiradęs klaidingas šventojo asmens skaidymas į Rusios apaštalą šv. Bonifacą ir Prūsijos misionierių šv. Brunoną. Būtent šv. Bonifacas $1673 \mathrm{~m}$. buvo paskelbtas šventuoju Lenkijos ir Lietuvos globeju. Ši diena Lietuvos vyskupijų kalendoriuose buvo minima birželio 19 d. semiduplex šventès rangu. Šita tradicija išliko ir po Respublikos žlugimo, XIX a. įsteigtose vyskupijose. Ypatingą reikšmę šv. Bonifaco minejjimas (birželio 18 d., vèliau - 19 d.) turejjo Mogiliavo arkivyskupijoje, kur šis šventasis buvo gerbiamas aukštesniu - duplex ir net duplex majus - šventès rangu kaip Rusijos arba Mogiliavo arkivyskupijos globėjas. 1925-1926 m. susikūrus Vilniaus ir Lietuvos bažnytinėms provincijoms ir peržiūrèjus LDK laikų liturginio kalendoriaus tradiciją, menkai žinomam šv. Bonifacui vyskupijų rubricelèse vietos nebeliko. I Vilniaus arkivyskupijos liturgini kalendoriu šv. Bonifacas (Brunonas) sugrąžintas tik XX a. 9 dešimtmečio pradžioje, patvirtinus privalomą minėjimą (memoria) liepos 12 d. (1987 m. jis perkeltas i liepos 13 d.). Pastaraisiais metais (2008-2009) šv. Brunono privalomas minejjimas Lietuvoje yra kovo 9 d. - kaip ir Visuotinès Bažnyčios kalendoriuje.

Lietuvos vienuolijų liturginiame kalendoriuje šv. Brunono (Bonifaco) gerbimu XVII-XIX a. išsiskyrè benediktinų ir kamaldulių ordinai. Benediktinai Lietuvoje paprastai minèjo arba šv. Bonifaco duplex rango šventę birželio 19 d., arba šv. Brunono atminimą spalio $15 \mathrm{~d}$. Be to, XVIII a. ryškẻja ir benediktinų praktika šv. Bonifacą minèti ne birželio 19 d., o birželio 20 d. Galbūt šis paprotys buvo perimtas iš kamaldulių, savo ordino šventaji minejjusių duplex II classis švente būtent birželio 20 d.?

Šv. Bonifaco (Brunono) gyvenimą pirmasis Lietuvoje 1579 m. Šventuju gyvenimuose lenkų kalba aprašè Petras Skarga. Jis rèmèsi šv. Petro Damianio pasakojimu. Šiuo liudijimu rèmèsi ir gerokai platesnio, pramanytomis detalemis bei prakalbomis praturtinto „gyvenimo” autorius - benediktinas Karolis Andrzejowskis, kuris 1768 m. Vilniuje išleido Benediktinų kalendorių. Pirmasis šv. Bonifaco „gyvenimas” lietuvių kalba buvo paskelbtas tik 1927 m., tačiau itin reikšminga buvo kun. Kazimiero A. Matulaičio parengta šv. Brunono biograma 1949 m. Čikagoje išleistuose Šventujų gyvenimuose. Autorius čia šv. Bonifacą susiejo su šv. Brunonu, lokalizavo jo misiją nebe Rusioje, o Prūsijoje (Prūsijos Rusneje), o pristatydamas šventojo gyvenimą šalia šv. Petro Damianio, plačiai rèmėsi ir Viperto liudijimu, bet svarbiausia - turbūt pirmasis akcentavo šv. Brunono misijos aktualumą Lietuvai. 